\title{
MARKETING NATURAL GAS: CANADIAN OVERVIEW
}

\author{
PHILIP H. DAVIES*
}

This article provides useful and brief background information on Canadian policy developments affecting the marketing of natural gas to the United States. Mr. Davies surveys the impact of the Canada-United States Free Trade Agreement; recent trends in bilateral gas trade; and current Canadian pipeline capacity. The article sets the context for others that follow in this issue.

\section{INTRODUCTION}

The purpose of this paper is to provide an overview of recent Canadian developments affecting the marketing of Canadian natural gas in the United States. The Free Trade Agreement will be briefly discussed, recent statistical information summarized and the capacity limitations of existing transportation systems delivering gas to the United States examined.

By providing the Canadian context, this paper will serve as an introduction to the paper to follow pertaining to gas marketing in the United States.

\section{FREE TRADE AGREEMENT}

The recent ratification of the Free Trade Agreement between Canada and the United States ${ }^{1}$ has raised the level of interest and expectation in bilateral trade between the two nations.

Chapter 9 of the Free Trade Agreement applies to trade in "energy goods" between Canada and the United States. A copy of Chapter 9 is attached, ${ }^{2}$ along with a Synopsis published by the Department of External Affairs. ${ }^{3}$ Of particular interest is Article 904, whereby the parties agree that export restrictions, while still permissible, may not reduce the proportion of an energy good exported to the other party relative to the total supply of that good, when compared to the proportion exported prior to the imposition of the restriction. Article 904 also prohibits the use of licences, fees, taxation, minimum price obligations or the like in respect of exports, when such restrictions are in fact imposed for reasons of short supply, conservation or domestic price stabilization.

The National Energy Board Act has been amended by the Canada-US Free Trade Agreement Implementation Act. ${ }^{4}$ That Act requires that the National Energy Board give effect to the Free Trade Agreement when exercising its powers. A copy of sections 142 and 143 of the Free Trade Implementation Act is attached. ${ }^{5}$ Those sections add to the National Energy Board Act, new sections 119.1 to 119.6 and amend section 120(e). Generally, those provisions permit the Governor General

* Staff Counsel, Alberta Energy Company Ltd., Calgary, Alberta

1. Canada-United States Free Trade Agreement Implementation Act, S.C. 1988, c. 65, Part A of Schedule.

2. See Appendix "A", to this paper.

3. Department of External Affairs, Government of Canada, "Canada-United States Free Trade Agreement - Synopsis" December 10, 1987, page 30. See excerpt included as Appendix "B".

4. Supra, note 1, proclaimed 1 January, 1989, except for Sections 61 to 65 (which deal with amendments to the Copyright Act).

5. Sections 142 and 143 of the Act are attached as Appendix " $C$ ". 
in Council to issue orders and to make regulations governing the interpretation to be given to the Free Trade Agreement by the National Energy Board. As of the date of writing this paper, no orders or regulations have been promulgated under those authorizing Sections.

In respect of the export of Canadian natural gas to the United States, the Free Trade Agreement will likely have little immediate impact. Volumes are presently moving at the practical upper limit of the transportation systems currently in place. However, the longer term impact of the Free Trade Agreement will be apparent when the supply and demand equation puts strain on Canadian productive capacity to meet Canadian demand. In those circumstances the provisions of Chapter 9 of the Free Trade Agreement will have more significance.

In summary, the Free Trade Agreement has assured United States buyers that their access to Canadian natural gas supplies will be as secure as that enjoyed by Canadian buyers, other factors being equal.

\section{RECENT TRENDS IN THE CANADIAN/UNITED STATES TRADE IN NATURAL GAS}

Canadian natural gas is presently enjoying an increasingly competitive advantage in United States markets. Exports from Canada climbed 36\% in the 1987/1988 contract year, compared to the $1986 / 1987$ contract year. (The contract year in the natural gas trade typically means the 12 month period beginning November 1st.) Total exports increased over that period from 921.8 billion cubic feet to 1.25 trillion cubic feet. ${ }^{6}$ Due to the warmer weather experienced during the first 4 months of the 1988/1989 contract year in most markets supplied by Canadian gas, the volume of exports, compared to the same period in the previous contract year, declined approximately $2.7 \% .^{7}$

Overall, Canadian natural gas enjoys a United States market share which has increased over the last 3 years from approximately $4 \%$ to approximately $7 \%{ }^{8}$

The two graphs which appear below are taken from the National Energy Board publication "Natural Gas Market Assessment".

Structure of Export Sales

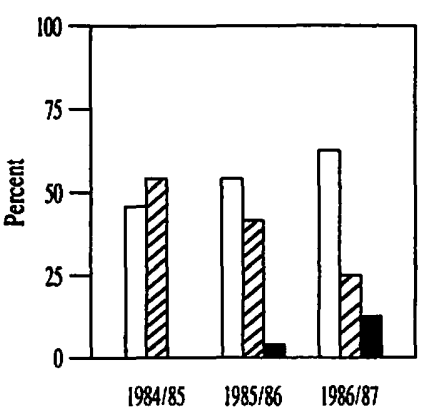

Structure of Export Arrangements

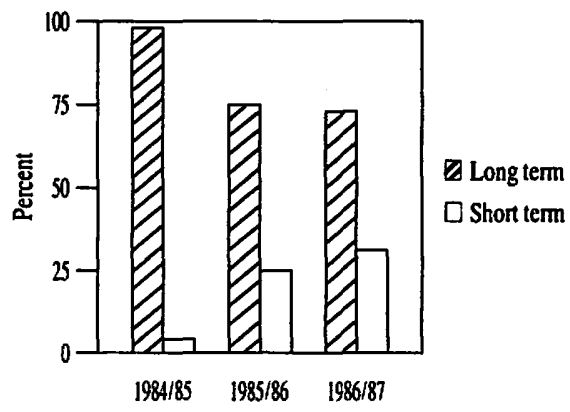

6. (1989) 2:7 Canadian Natural Gas Focus 8.

7. National Energy Board, "Natural Gas Exports and Imports, Monthly Statistics for February 1989", (Gas and Oil Branch, Regulatory Surveillance Division).

8. National Energy Board Annual Report, 1988 at 13.

9. National Energy Board, "Natural Gas Market Assessment", October, 1988 at 44. 
The graphs confirm a trend of movement from long-term to short-term sales and of increasing importance of sales to local distributing companies and brokers at the expense of sales to interstate pipelines. During the first 4 months of the $1988 / 1989$ contract year, long-term exports declined $11.4 \%$ whereas short-term exports increased by $17.6 \% .^{10}$

Increasingly, direct sales are being made to United States buyers in the industrial sector and the electrical generation sector. The American Gas Association in its January 3, 1989 issue of "Planning and Analysis Issues" forecast gas consumption to increase (in its base case) by $3.2 \%$ in contract year 1988/1989. It attributes that increase to the industrial sector (with a forecast increase of $5.2 \%$ ) and to electrical generation (with a forecast increase of $6.7 \%$ ). $"$

In summary, recent trends in the international trade of Canadian natural gas show an increasing movement towards shorter term, direct relationships and of increasing penetration of Canadian natural gas in the United States market.

\section{PIPELINE CAPACITY FOR EXPORT MARKETS}

Kenneth W. Vollman, Member of the National Energy Board, in his remarks to a Cross Border Seminar held in Calgary December 1,1988, indicated that no major gas pipeline construction under federal jurisdiction has occurred in Canada during the previous 5 years. Spare capacity has now largely disappeared; indeed there is presently no firm capacity to be had on any federally regulated pipeline (with the exception of the Westcoast system). Mr. Vollman's remarks echo those of the National Energy Board staff found in the "Natural Gas Market Assessment" referred to above. ${ }^{12}$

Overall, Canadian gas transmission systems operated at extremely high utilization rates during the peak winter demand period of January and February 1988 - on average over $90 \%$. The following table sets forth the utilization rates of specific pipelines during that peak demand period for 1986-1989: ${ }^{13}$

\section{PIPELINE UTILIZATION DURING JANUARY AND FEBRUARY}

\section{Capacity}

(PJ)

$\begin{array}{lr}\text { Westcoast } & 95 \\ \text { NOVA } & 450 \\ \text { ANG } & 100 \\ \text { Foothills } & 70 \\ \text { TCPL (West) } & 280 \\ \text { TCPL (Central) } & 120\end{array}$

Two-Month Percent Utilization

\begin{tabular}{llll}
\hline 1986 & 1987 & 1988 & $\begin{array}{c}1989 \\
\text { (Forecast) }\end{array}$
\end{tabular}

$\begin{array}{llll}75 & 79 & 78 & 83 \\ 80 & 75 & 92 & 93 \\ 70 & 93 & 99 & 99 \\ 46 & 34 & 96 & 96 \\ 91 & 80 & 88 & 90 \\ 98 & 97 & 99 & 99\end{array}$

10. Supra, note 7.

11. American Gas Association, "Planning and Analysis Issues", Issue 89-1, January 3, 1989.

12. Supra, note 9 at 63 .

13. Supra, note 9 at 55 . 
This high level of utilization has brought increased curtailment of interruptible transportation and threatens to severely constrain the near term feasibility of new export proposals.

Both NOVA and TransCanada PipeLines have announced or applied for significant improvements to their respective pipeline systems to permit incremental volumes to be transported. "Canadian Natural Gas Focus" recently provided an overview of the various Canadian gas pipeline expansion proposals currently under consideration. ${ }^{14}$ It reported that during the current year, NOVA plans to spend $\$ 320$ million to boost field-receipt capacity and that during the 1990/1991 contract year it plans to spend $\$ 300$ million to increase export delivery capability. These improvements are expected to increase capacity by 660 million cubic feet per day.

"Canadian Natural Gas Focus" also reported ${ }^{15}$ that TransCanada PipeLines has applied for approval to construct new facilities to increase, effective November 1,1989 , its capacity by 450 million cubic feet per day. Approximately $60 \%$ of that capacity is reserved for United States markets. TransCanada has also applied for approval to spend a further $\$ 652$ million to expand capacity, effective November 1,1990 , by a volume of 532.5 million cubic feet per day. In that case, approximately 443 million cubic feet per day - in excess of $83 \%$ - is intended to serve United States markets.

In addition to the above, expansions are proposed or anticipated on the Alberta Natural Gas Company system and the Foothills Pipeline system (eastern leg). Considerable interest is also being shown in the applications before the National Energy Board to export McKenzie Delta gas and in the revival of the proposals to transport such gas.

To the extent the above expansions take place (along with the related United States facilities) significant incremental gas marketing opportunities to major United States markets are secured.

\section{CONCLUSION}

The purpose of this paper was to provide a brief overview of Canadian developments impacting the marketing of Canadian natural gas in the United States. Because of its brevity, the paper is lacking in both scope and depth. However, it is hoped that the summary it provides will sketch a background for the detailed gas marketing paper to be presented by Douglas F. John. That paper deals extensively with regulatory considerations pertaining to the importation, transportation and sale of natural gas in the United States and discusses several proposals for new or expanded facilities to permit United States buyers increased access to Canadian gas.

14. (1989) 2:8 Canadian Natural Gas Focus 5.

15. Supra, note 14 at 6. 


\section{APPENDIX "A" \\ EXCERPT FROM THE \\ CANADA-UNITED STATES FREE TRADE AGREEMENT PART “A" OF SCHEDULE TO CHAPTER 65 STATUTES OF CANADA, 1988}

\section{Chapter Nine}

\section{Energy}

Article 901: Scope

1. This Chapter applies to measures related to energy goods originating in the territory of either Party.

2. For purposes of this Chapter, energy goods refer to those goods classified in the Harmonized System under:

a) Chapter 27 (except headings 2707 and 2712);

b) subheading 2612.10 ;

c) subheadings 2844 .10 through 2844.50 (only with respect to uranium compounds classified under those subheadings); and

d) subheading 2845.10 .

Article 902: Import and Export Restrictions

1. Subject to the further rights and obligations of this Agreement, the Parties affirm their respective rights and obligations under the General Agreement on Tariffs and Trade (GATT) with respect to prohibitions or restrictions on bilateral trade in energy goods.

2. The Parties understand that the GATT rights and obligations affirmed in paragraph 1 prohibit, in any circumstances in which any other form of quantitative restriction is prohibited, minimum export price requirements and, except as permitted in enforcement of countervailing and anti-dumping orders and undertakings, minimum import-price requirements.

3. In circumstances where a Party imposes a restriction on importation from or exportation to a third country of an energy good, nothing in this Agreement shall be construed to prevent the Party from:

a) limiting or prohibiting the importation from the territory of the other Party of such energy good of the third country; or

b) requiring as a condition of export of such energy good to the territory of the other Party, that the good be consumed within the territory of the other Party.

4. In the event that either Party imposes a restriction on imports of an energy good from third countries, the Parties, upon request of either Party, shall consult 
with a view to avoiding undue interference with or distortion of pricing, marketing and distribution arrangements in the other Party.

5. The Parties shall implement the provisions of Annex 902.5

\section{Article 903: Export Taxes}

Neither Party shall maintain or introduce any tax, duty, or charge on the export of any energy good to the territory of the other Party, unless such tax, duty, or charge is also maintained or introduced on such energy good when destined for domestic consumption.

\section{Article 904: Other Export Measures}

Either Party may maintain or introduce a restriction otherwise justified under the provisions of Article XI:2(a) and XX (g), (i) and (j) of the GATT with respect to the export of an energy good of the Party to the territory of the other Party, only if:

a) the restriction does not reduce the proportion of the total export shipments of a specific energy good made available to the other Party relative to the total supply of that good of the Party maintaining the restriction as compared to the proportion prevailing in the most recent 36 -month period for which data are available prior to the imposition of the measure, or in such other representative period on which the Parties may agree;

b) the Party does not impose a higher price for exports of an energy good to the other Party than the price charged for such energy good when consumed domestically, by means of any measure such as licences, fees, taxation and minimum price requirements. The foregoing provision does not apply to a higher price which may result from a measure taken pursuant to subparagraph (a) that only restricts the volume of exports; and

c) the restriction does not require the disruption of normal channels of supply to the other Party or normal proportions among specific energy goods supplied to the other Party such as, for example, between crude oil and refined products and among different categories of crude oil and of refined products.

\section{Article 905: Regulatory and Other Measures}

1. If either Party considers that energy regulatory actions by the other Party would directly result in discrimination against its energy goods or its persons inconsistent with the principles of this Agreement, that Party may initiate direct consultations with the other Party. For purposes of this Article, an "energy regulatory action" shall include any action, in the case of Canada, by the National Energy Board, or its successor, and in the case of the United States of America, by either the Federal Energy Regulatory Commission or the Economic Regulatory Administration or their successors. Consultations with respect to the actions of these agencies shall include, in the case of Canada, the Department of Energy, Mines and Resources and, in the case of the United States of America, the Department of 
Energy. With respect to a regulatory action of another agency, at any level of government, the Parties shall determine which agencies shall participate in the consultations.

2. In addition, the Parties shall implement the provisions of Annex 905.2.

Article 906: Government Incentives for Energy Resource Development

Both Parties have agreed to allow existing or future incentives for oil and gas exploration, development and related activities in order to maintain the reserve base for these energy resources.

Article 907: National Security Measures

Neither Party shall maintain or introduce a measure restricting imports of an energy good from, or exports of an energy good to, the other Party under Article XXI of the GATT or under Article 2003 (National Security) of this Agreement, except to the extent necessary to:

a) supply a military establishment of a Party or enable fulfillment of a critical defence contract of a Party;

b) respond to a situation of armed conflict involving the Party taking the measure;

c) implement national policies or international agreements relating to the nonproliferation of nuclear weapons or other nuclear explosive devices; or

d) respond to direct threats of disruption in the supply of nuclear materials for defence purposes.

Article 908: International Obligations

The Parties intend no inconsistency between the provisions of this Chapter and the Agreement on an International Energy Program (IEP). In the event of an unavoidable inconsistency between the IEP and this Chapter, the provisions of the IEP shall prevail to the extent of that inconsistency.

Article 909: Definitions

For purposes of this Chapter:

consumed means transformed so as to qualify under the rules of origin set out in Chapter Three, or actually consumed;

restriction means any limitation, whether made effective through quotas, licences, permits, minimum price requirements or any other means;

total export shipments means the total shipments from total supply to users located in the territory of the other Party; and

total supply means shipments to domestic users and foreign users from

a) domestic production,

b) domestic inventory, and

c) other imports, as appropriate. 
Annex 902.5

Import Measures

1. The United States of America shall exempt Canada from any restriction on the enrichment of foreign uranium under section 161v of the Atomic Energy Act.

Export Measures

2. Canada shall exempt the United States of America from the Canadian Uranium Upgrading Policy as announced by the Minister of State for Mines on October 18, 1985.

3. The United States of America shall exempt Canada from the prohibition on the exportation of Alaskan oil under section 7(d) of the Export Administration Act of 1979, as amended, up to a maximum volume of 50 thousand barrels per day on an annual average basis, subject to the condition that such oil be transported to Canada from a suitable location within the lower 48 states.

Annex 905.2

Regulatory and Other Measures

\section{Canada}

1. Of the tests set out under subparagraph 6(2)(z) of the National Energy Board Part VI Regulations on the export of energy goods to the United States of America, Canada shall eliminate the "least cost altemative test", described in subparagraph 6(2)(z)(iii).

\section{United States of America}

2. The United States of America shall cause the Bonneville Power Administration to modify its Intertie Access Policy so as to afford British Columbia Hydro treatment no less favourable than the most favourable treatment afforded to utilities located outside the Pacific Northwest.

3. No other policy of the Bonneville Power Administration or law authorizing such policy need be changed insofar as such law or policy concerns energy sales, transmission of energy and related business arrangements between the Bonneville Power Administration and British Columbia Hydro.

\section{General}

4. It is understood that the implementation of this Chapter includes the administration of any "surplus tests" on the export of any energy good to the other Party in a manner consistent with the provisions of Articles 902, 903 and 904. 
5. The Parties fully expect that the Bonneville Power Administration and British Columbia Hydro will continue to negotiate mutually beneficial arrangements consistent with the objectives of this Agreement and separately to seek any additional authorities that may be needed.

\section{APPENDIX “B” \\ EXCERPT FROM THE \\ CANADA-UNITED STATES FREE TRADE AGREEMENT SYNOPSIS

\author{
PUBLISHED BY \\ THE DEPARTMENT OF EXTERNAL AFFAIRS \\ GOVERNMENT OF CANADA
}

DECEMBER 10, 1987

\section{Chapter Nine: Trade in Energy}

Over the past decade, bilateral trade in energy has assumed increasing importance to Canadians. Canada exports more than $\$ 10$ billion in energy products annually, including oil, gas, electricity and uranium. Billions more are exported in the form of downstream products such as various oil and gas derivatives. That trade provides a livelihood for thousands of Canadians. Some of these exports, however, are limited or threatened by U.S. restrictions and regulatory actions, including restrictions on exports of upgraded Canadian uranium, discriminatory price actions on natural gas, tariffs and threatened import fees on crude oil and products, and threatened restrictions on electricity.

This chapter, which reproduces some of the provisions of Chapter Four as they relate to energy goods, will secure Canada's access to the United States market for energy goods. The two countries have recognized that they have a common interest in ensuring access to each other's market and enhancing their mutual security of supply. They have, therefore, built on their existing GATT rights and obligations and agreed that, as each other's best customers, they should get fair treatment should there be any controls on energy commodities. Both remain free to determine whether and when to allow exports and may continue to monitor and license exports.

Article 902 affirms Canadian and U.S. rights and obligations under the GATT on trade restrictions in energy products. This includes a prohibition on minimum export or import price commitments. More particularly, the United States has agreed to eliminate all U.S. restrictions on the enrichment of Canadian uranium and Canada will eliminate the requirement for uranium to be processed before it is exported to the U.S. The United States has also agreed to end its total embargo on exports of Alaskan crude oil and allow Canadians to import up to 50,000 barrels a day. These commitments are described in Annex 902.5.

Where either Canada or the U.S. applies import or export restrictions to energy trade with other countries, it may limit or prohibit the pass-through of imports from those other countries into its own territory. It may also require, in such instances, that its exports to the other be consumed within the other's territory. 
Article 903 on export taxes restates the obligation of Chapter Four not to impose taxes or charges on exports unless the same tax is applied to energy consumed domestically. Article 904 on other export measures restates the obligations of Chapter Four that export restrictions may not reduce the proportion of the good exported to the other party relative to the total supply of the good compared to the proportion exported prior to the imposition of the restriction. It also prevents the use of licenses, fees or other measures to charge higher prices for exports when such restrictions are used for short supply, conservation or domestic price stabilization reasons.

This article also provides that export restrictions not be designed to disrupt normal channels of supply or alter the product mix as between various types of specific energy goods exported to the other country. For example, if Canada in future decides to implement measures to limit the consumption of oil, it can reduce exports to the United States proportional to the total supply of oil available in Canada. Any such restrictions must not be designed to disrupt normal trade patterns.

The two countries have also agreed to allow existing or future incentives for oil and gas exploration and development in order to maintain the reserve base for these energy resources.

The chapter recognizes the important role played by the National Energy Board in Canada and the Federal Energy Regulatory Commission and the Economic Regulatory Administration in the United States. If discrimination inconsistent with this agreement results from a regulatory decision, direct consultations can be held with a view to ending any discriminatory action, such as the decisions earlier this year by the Federal Regulatory Commission prohibiting Canadian suppliers of natural gas from passing all their shipment costs on to their customers.

In Annex 905.2, Canada undertakes to eliminate one of three price tests which the National Energy Board (NEB) applies to exports. Through these tests, the NEB assesses whether all costs have been recovered, whether the offered price would not be less than the cost to Canadians for equivalent service, and whether the offered price would be materially less than the least cost alternative for the buying entity. It is this "least cost alternative test" only which is being eliminated.

The United States will require the Bonneville Power Administration to treat British Columbia Hydro no less favourably with respect to access to power transmission lines than utilities located outside the US Pacific Northwest. The two governments state their expectation that Bonneville Power and British Columbia Hydro will continue to negotiate mutually beneficial arrangements on the use of power transmission lines.

Article 907 provides a tighter national security exception than is contained in the GATT and for the agreement as a whole, while Article 908 indicates that the provisions of the Agreement on an International Energy Program, which governs trade in oil during tight supply conditions, take precedence over the provisions of this chapter. 


\section{APPENDIX "C" \\ EXCERPT FROM THE \\ CANADA-UNITED STATES FREE TRADE AGREEMENT \\ IMPLEMENTATION ACT}

STATUTES OF CANADA, 1988

\section{CHAPTER 65}

\section{National Energy Board Act}

142. The National Energy Board Act is amended by adding thereto, immediately after section 119 thereof, the following heading and sections:

\section{"Implementation of Free Trade Agreement}

119.1 In this section and sections 119.2 to 119.6 ,

"Agreement"' has the same meaning as in the Canada-United States Free Trade Agreement Implementation Act;

"energy goods" means energy goods within the meaning of Chapter Nine of the Agreement for the exportation of which a licence issued under this Part or an order made under the regulations is required;

"United States" has the same meaning as in section 2 of the Canada-United States Free Trade Agreement Implementation Act.

119.2 (1) In exercising its powers and performing its duties, the Board shall give effect to the Agreement.

(2) The Governor in Council may, either on the recommendation of the Minister made at the request of the Board or on the Governor in Council's own motion, make orders of general application respecting the manner in which the Board shall perform the duty imposed on it by subsection (1) or the interpretation to be given to the Agreement by the Board for the purposes of this Act.

(3) An order made under subsection (2) is binding on the Board from the time it comes into force and, unless otherwise provided therein, applies in respect of matters pending before the Board at that time.

(4) The Board may, in order to request the making of an order under subsection (2), suspend the determination of any matter of which it is seized.

119.3 The Governor in Council may, by order, declare that the maintenance or introduction of a restriction on the exportation to the United States of energy goods or of any quality, kind or class thereof is justified under Article 904 of the Agreement. 
119.4 Where, in the course of determining an application for a licence, or determining whether to make an order, for the exportation to the United States of energy goods or of any quality, kind or class thereof, the Board considers that the maintenance or introduction of a restriction on that exportation is in the public interest and that subparagraph $(a),(b)$ or $(c)$ of Article 904 of the Agreement would apply as a consequence of the restriction, the Board may, in order to request that the Minister recommend to the Governor in Council that an order be made under section 119.3 in respect of the relevant energy goods, suspend the determination until not later than one hundred and twenty days after the request is made.

119.5 (1) The Board may neither refuse to issue a licence or make an order nor revoke, suspend, change, alter or vary a licence or order for the exportation to the United States of energy goods or of any quality, kind or class thereof where that refusal, revocation, suspension, change, alteration or variation would constitute the maintenance or introduction of a restriction on that exportation as a consequence of which subparagraph $(a),(b)$ or $(c)$ of Article 904 of the Agreement would apply.

(2) Subsection (1) does not apply in respect of the exportation to the United States of such energy goods as are, or of such quality, kind or class thereof as is, referred to in an order made under section 119.3 during the time that the order is in force.

(3) Notwithstanding subsection (1), the Board may revoke, suspend, change, alter or vary a licence or order on the application or with the consent of its holder.

119.6 The Board may, despite its not being satisfied in accordance with paragraph 118 $(a)$, issue a licence for the exportation to the United States of such energy goods as were, or of such quality, kind or class thereof as was, referred to in a request made under section 119.4 if

(a) the Minister declines to recommend to the Governor in Council that an order be made under section 119.3;

(b) the Governor in Council declines to make the order; or

(c) no order is made within one hundred and twenty days after the making of the request."

143. Subsection 120(2) of the said Act is repealed and the following substituted therefor:

“(2) The Governor in Council may make regulations

(a) prescribing, in respect of oil or gas the export of which is authorized under this Part, or any quality, kind or class of that oil or gas or type of service in relation thereto, the price at which or the range of prices within which that oil or gas shall be sold; and

(b) exempting oil or gas that is exported to the United States, or any quality, kind or class of that oil or gas or type of service in relation thereto, from the application of regulations made under paragraph $(a)$.

(3) Regulations made under subsection (2) may prescribe different prices or ranges of prices in respect of different countries.' 